Crop Breeding and Applied Biotechnology 13: 9-22, 2013

Brazilian Society of Plant Breeding. Printed in Brazil

REVIEW

\title{
Implications on the introduction of transgenics in Brazilian maize breeding programs
}

\author{
Sidney Netto Parentoni ${ }^{*}$, Rubens Augusto de Miranda ${ }^{1}$ and João Carlos Garcia ${ }^{1}$
}

Received 15 September 2012

Accepted 20 December 2012

\begin{abstract}
Transgenic maize was approved in Brazil in 2008/2009. In 2012, it occupied 73\% of the country maize growing area. This high adoption rate confirms studies indicating that technology use has been the major driving force in Brazilian agriculture. Maize seed market in the world has been a concentrated sector. Although, when this sector is associated with transgenesis, this concentration increases sharply. In one side, there is the idea that companies can benefit from gains of scale and complementarities to maximize their efficiency in research and development $(R \& D)$. On the other side, this concentration may allow the exercise of "market power" by dominant companies. The objective of this study is to analyze the impacts of the adoption of transgenic technology in the arrangements of maize breeding programs and seed production sector in Brazil. A critical analysis of the situation of the breeding programs that do not have this technology is made.
\end{abstract}

Key words: Maize breeding, seed market concentration, transgenesis.

\section{INTRODUCTION}

Biotechnology and transgenesis have shown great value as complementary technological tools for cultivar development, which can add to these cultivars specific characteristics that would be difficult to obtain using conventional breeding. In the specific case of maize, the genetic modifications known as "first generation" have focused on insect resistance and herbicide tolerance traits. In July 2012, thirty-four transgenic products of maize, cotton and soybeans were commercially approved by the Brazilian Biosafety Technical Commission (CTNBio); eighteen of them are transgenic maize.

In different situations, questions have been raised related to the possible negative impacts of transgenic crops to human health or to environmental risks. However, to date, there is no scientific evidence of these risks in the genetic modified technology released for commercial use in the country. Instead, its high rate of adoption in Brazil indicates that this technology has contributed to the solution of some important demands of the farmers: technologies that reduce risk (e.g., control of fall armyworm using $B t$ technology) and an increase in operational convenience (e.g. larger and easier to do herbicide spraying period, as in $R R$ technology). However, the changes that the adoption of these technologies have brought to the arrangement of breeding programs to the companies that can't directly have access to these technologies and the consequences in the medium and long term that this technology may bring to the country have been slightly analyzed under a national strategic vision.

Allogamous seed market worldwide generally shows a higher level of concentration than what is observed in autogamous crops. The reason is that the exploration of heterosis using hybrids as well as intellectual property guaranteed by the ownership of parental inbred lines have allowed the private sector, in allogamous crops, to be more efficient in obtaining financial support oriented for breeding programs. This has resulted in increased investments for innovation in genetics and biotechnology in this sector. The high investment required to develop a new transgenic product from the research phase to its worldwide deregulation in import markets (required in the case of commodities) led to a concentration of the world market for maize seeds in this last decade much higher than what was observed at the beginning of the 90s (Howard 2009). The cost for developing transgenic innovations has greatly reduced the number of companies with sufficient availability of resources to participate in this activity. This has constituted as a bar-

${ }^{1}$ Embrapa Milho e Sorgo, C.P. 151, 35.701-970, Sete Lagoas, MG, Brazil. *E-mail: sidney.parentoni@embrapa.br 
rier to the use of this technology by other companies. This barrier is much larger than that represented by the costs of conventional breeding programs. Besides the technological innovation in seed component, the large chemical corporations that now dominate this market have included extensive marketing programs coupled with an aggressive commercial verticalization policy (simultaneous sale of agricultural inputs such as seeds and pesticides, technical assistance and, occasionally, crop financing and purchase of grain production). This model is now consolidated in the United States, where public maize breeding programs (mainly at the Universities) and independent programs on small and medium companies, which do not have technological alliance with the trait holders, have almost disappeared. The concentration in seed and biotechnology sector can be seen by looking at the market share of the eight largest firms which was 29\% in 1994 and raised to $63.4 \%$ in 2009 (Fuglie et al. 2012b).

The phenomenon of globalization and concentration of companies have proved to be universal in areas like telecommunications, information technology, production of cell phones, automotive industry, banking and others. An interesting point is that most of the products and services offered by these segments can be developed and manufactured anywhere in the world and are easily transferred to the market where it will be sold. In agriculture, considerations relating to food biosafety and environmental impacts require greater local action of companies, so that legal requirements of each country are observed. This implies in a high operational cost, which can only be funded by companies with large financial and organizational capability. In the case of the Brazilian economy, which is still strongly based on agriculture, the development of new cultivars, their seed production and efficiency tests of events against pests and weeds, for example, must be conducted locally. Brazil is a country of continental proportions, with a diversity of soils and environments that range from subtropical areas to latitudes close to the Equator. The savannah area (known as Cerrado), for instance, presents great variation in rainfall and a mosaic of altitudes, ranging from sea level to above a thousand meters plateaus. Moreover, there are at least two cropping seasons in the country (first and second crops), with different soil conditions, temperature and rainfall. This variety of environments, and consequently the biotic and abiotic stresses that affect crops in the country, is bigger than those present in the United States Corn Belt, for example. This becomes a challenge for breeding programs in Brazil, especially when considering broad adaptation strategies versus specific adaptation strategies in cultivar selection.

As part of these large biodiversity in Brazil compared to other temperate countries, it should be expected that more problems would be faced by the transgenic technology in tropical conditions with two cropping seasons per year. In fact, in the 2012/2013 summer season in Brazil, a number of reports from farmers and agronomists have indicated the occurrence of fall armyworm (Spodoptera frugiperda) attacks higher than it would be expected in some fields with transgenic $B t$ maize. At this moment, there is no explanation if more extreme weather conditions or other factors should be influencing this situation. The new stacked events with two or more $B t$ genes have shown higher levels of resistance than some single gene events in the conditions described above, but it should be expected that the gene stacking option alone also would not be a unique durable solution for the insect control problem. At the beginning, $B t$ technology was seen by farmers as a single solution to solve all their problems related to target insects. Farmers in Brazil stopped doing "Integrated Pest Management System" (IPM) and in some cases also abandoned other recommended practices such as the planting of refuge areas with conventional materials. It is becoming clear that transgenics for insect control is one important tool that should be used as part of an IPM and not as a single strategy. In this regard, private $\mathrm{x}$ public partnerships would be valuable tools to develop and implement IPM systems.

As mentioned above, seed market concentration has a number of different implications to be considered. In the case of maize seed industry, one point to be analyzed is related to the logistics of seed distribution in different regions of a large country such as Brazil and also for the two annual cropping seasons. This means that in a situation of a highly concentrated seed market, with few companies, a frustration in seed production in one of these large companies, or even an unexpected change in seed demand, could reduce access to seed input, and unpredictably affect maize production in the country, which is the basis of all national chain of meat and dairy products.

Thus, the existence of a larger number of breeding programs and maize seed industries seem to be good for the national economy by increasing the variability of cultivated germplasm in the country (which reduces vulnerability to biotic risks, like new pests and diseases), increasing seed distribution channels (local firms may specialize in meeting the demands of a particular geographic area, and of certain technological segments that complement the performance of larger companies) and improving the buffering capacity and regulation of seed prices in these markets.

\section{GENERAL INFORMATION ON MAIZE SEED MARKET CONCENTRATION AND BRAZILIAN AGRICULTURE}

In order to explore the potential synergy between different areas, in the 1990s and early 2000s, a series of mergers and acquisitions among pharmaceutical, agrochemical and 
seed industries was observed worldwide (Fernandez-Cornejo 2004, Howard 2009).

In Brazil, the wave of mergers and acquisitions that restructured the international seed market began in the late 1990s. At that time, Brazil had about twenty-two companies with their own maize breeding programs in the country, including nineteen private companies (five of which were multinationals), and three public companies (Embrapa, CATI and IAC). Embrapa (Brazilian Agriculture Research Company) had formed a group of about 28 licensed companies (called "Unimilho"). Altogether, approximately fifty companies were selling maize seeds in the country in the 1990s (Antonialli 2012).

The acquisition of seed companies in the country by large international groups (mainly from the pharmaceutical and agrochemical areas) was a strategy that these groups found to obtain new assets (germplasm and structures of production, distribution and marketing of seeds available in the country) which would complement and add value to the assets they already possessed, like biotechnology and capital (Guerrante 2011). The acquisitions that occurred in 2011 and 2012 indicate that this process is still ongoing. Table 1 presents the major acquisitions in the sector, which has restructured the Brazilian maize seed market.

Table 1. The most important mergers/acquisitions of maize seed company in Brazil

\begin{tabular}{ll}
\hline Acquiring Company & Acquired Company \\
\hline Monsanto & $\begin{array}{l}\text { Agroceres, Cargill, Braskalb and Agroeste } \\
\text { Dinamilho, FT Biogenética, Híbridos Colo- } \\
\text { rado, Hatã, Agromen } \\
\text { Bayer-Sementes Brasil (formed from the } \\
\text { acquisition of Ribeiral, Mogiana, Fartura and } \\
\text { Mitla) }\end{array}$ \\
Lidera & $\begin{array}{l}\text { Brasmilho (formed of Planagri, Semel, For- } \\
\text { tuna and Semear) and Guerra-PR }\end{array}$ \\
KWS & Riber, Delta and Semilla \\
\hline
\end{tabular}

Source: Own elaboration

However, one must consider that the business of maize seeds in the country had already presented a tradition of concentration over the $80 \mathrm{~s}$ and the $90 \mathrm{~s}$. As an example, during that time, the company Agroceres (Brazilian company which was acquired by Monsanto in 1999) held close to $40 \%$ of the country maize seed market share. In the new scenario, the concentrated market structure remained, but the seed market started to be almost completely controlled by chemical companies.

The effects of the concentration in the seed market still lack studies, but in theory they could result in two different situations. On the one hand, there is the idea that the seed companies can benefit from gains of scale and complemen- tarities to increase the efficiency of their R\&D. On the other hand, there is the possibility that the concentration allows the use of market power by dominant companies. This latter situation may result in reduced rates of innovation in the sector and/or higher seed prices. The first analysis of these conflicting aspects in biotechnology between concentration and increased ability of innovating (known as "competition and efficiency") versus aspects of total market control (known as "equity") was made in a pioneering work by Elzinga (1977). This author analyzed that a balance between competition and concentration (regulated by the market) and the antitrust laws (regulated by the State) should occur in order to ensure both the innovative power of companies and the society's interests.

Schimmelpfenning et al. (2004) investigated the impacts of changes in the market of maize, cotton and soybeans in the United States, and found evidence of an inverse relationship between the concentration and amount of research. Silva et al. (2012) conducted a similar study in Brazil, covering the same markets. Among the findings of these last authors, it is noteworthy that, despite the centralizing trend in the analyzed period (1999 to 2010), there is no evidence of exercise of market power on prices, productivity of innovations and change in the number of registers in the National Cultivar Registration System - RNC. In relation to maize, the results of Silva et al. (2012) should be analyzed as a preliminary view, since the advent of transgenic seeds was still incipient at the time of the study (only two years of commercialization), and marketing such technology is clearly a structural break.

Fuglie et al. (2012b) analyzed the effects of concentration in industry agriculture inputs. The authors mention that farm inputs have been rising faster than the prices farmers receive for their crops in the U.S. The largest increase over 1990-2010 was in crop seed prices, which more than doubled relative to the price received for agricultural commodities.

Shin and Chavas (2010) and Shin et al. (2010b) found evidences that in the American market, the prices of soybean and cotton, respectively, tend to be higher in verticalized arrangements or in authorization for distribution than in those observed in the transfer of transgenic technology by licensing it. In the latter, the authors conclude that "this indicates that vertical integration achieved by biotechnology companies could increase the exercise of the market power and the ability of companies to obtain economic benefits from retail seed stores and farmers".

Currently, the market for transgenic maize in the U.S. is dominated by seeds planted with 2-4 stacked events, but it is possible to find seeds stacked up to 8 events. This procedure does not blow up the prices of seeds by the fact that the pricing of each event occurs in a sub-additive way. In other words, the additional events incorporate a value less than proportional to the premium paid for a single 
event in a seed (Shin et al. 2010a). More studies related to the impacts of market concentration of seeds in Brazil are required to support public policies in this area.

Despite the commercial production of genetic modified grains started in the mid-1990s in the United States, in Brazil the technology was first used in maize fields only in the 2008/09 crop and in small quantities. The maize crop of $2011 / 12$ is the third season in which the availability of genetically modified maize seed is relevant in terms of quantity and trait options for farmers. During this crop season, the use of genetic modified seeds, in total seed market, was $73 \%$ (summer 2011/12) versus $36 \%$ in the summer crop of $2009 / 10$, indicating a wide domain of this technology in the commercial seed market. The Brazilian second cropping season called "safrinha" can be defined as a crop rotation is to first plant a crop of rain-fed such as soybean or rice, and then after these crops are harvested, plant a second crop of maize, sorghum, cotton or wheat. Safrinha can also be defined as a farming strategy whereby the farmer takes advantage of a long tropical growing season to produce two crops in a single growing season, thereby maximizing revenue per hectare. This new fact also causes concerns because genetic modified crops (GMO) are planted after GMO crops, and insects are always exposed to crops even during the dry season. In Brazilian second crop, the percentage of transgenic maize seed rose from $39 \%$ (in 2010) to $64 \%$ (in 2011), reaching $83 \%$ of the marketed seeds in 2012.
The situation above refers to the relative participation of transgenic events regarding the sale of seeds. In the summer crop, there is a reasonable percentage of less technified farmers, especially in the North and Northeast of Brazil, which use their own seeds (saved from previous crops), or open pollinated varieties seed distributed by governmental programs, and this covers more than 2 million hectares. In this sense, considering the total area planted with maize in the country (which includes crops planted with commercial seed and crops planted with seeds saved by farmers) the percentage of use of transgenic seeds decreases to $53.5 \%$ (2011/12 crop) during summer plantings.

\section{RISKS ASSOCIATED WITH THE CONCENTRATION OF THE MAIZE SEED INDUSTRY IN BRAZIL}

In the case of maize seed market in Brazil, there is a concern with the fact that the widespread use of transgenic technology may lead to an excessive concentration of this market. However, the market for maize seeds has a high degree of concentration due to the predominance of hybrid cultivars (whose development requires investment in research), and to the high expenses needed in programs of seed quality, post-sales and marketing activities. When considering only the transgenic seed market, the structure is even more concentrated. It can be observed in Table 2 that the events of genetic modified seeds of Monsanto, DuPont-Pioneer and

Table 2. Sale of transgenic maize seed separated by type of event, from 2009/2010 to 2011/2012, in Brazil

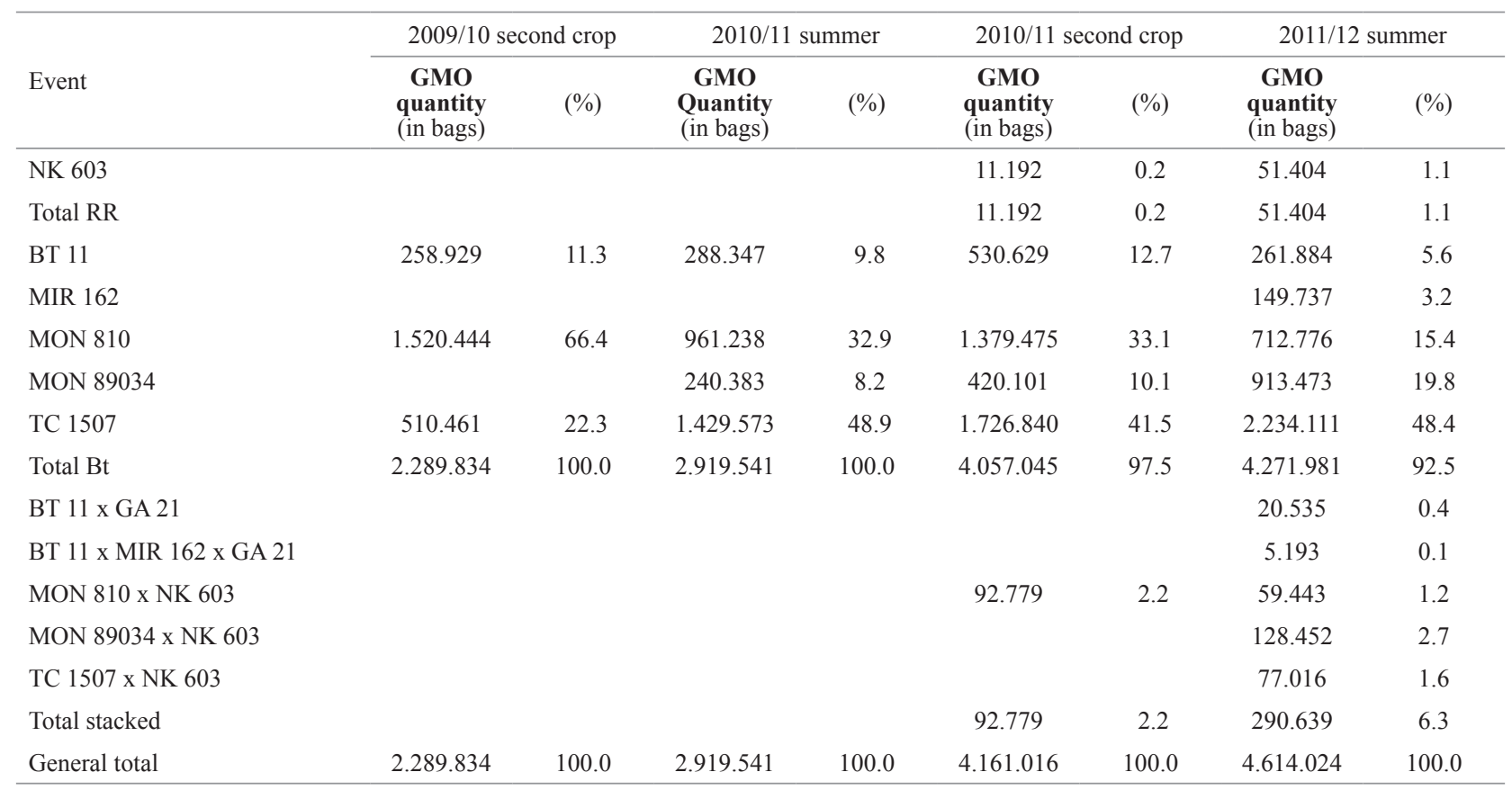

Source: Data from “Associação Paulista dos Produtores de Sementes e Mudas" (APPS) 
Dow have a market share over $90 \%$ related to the total maize seed with transgenic events in the Brazilian market.

Table 3 shows the availability of maize cultivars in the Brazilian market for the next crop and for the last seven crop seasons. There was a sharp increase in the number of cultivars that have been made available by companies in the early commercialization stages of genetic modified seeds. This was due to the fact that the new transgenic cultivars were versions of pre-existing conventional cultivars which were made available with new traits. After the peak in 2010/2011 cropping season, when 497 cultivars were made available, this cultivar number has been dropping. It is noteworthy that, despite of the high number of cultivars registered in the country, in fact, an analysis of cultivars that would occupy $80 \%$ of the maize growing area in the country in a given year, will be a much smaller fraction than the numbers shown above. However, this evaluation must be done carefully, since there is not enough information to analyze accurately and reliably the possibility of a decrease in the speed of new products releases by breeding programs. It should be pointed out that the continuous release of new cultivars with higher yield potential and yield stability is what will ensure the growth of crop productivity in the country. So far, transgenic events have been used to promote crop protection (as in insect resistant traits), or to facilitate field operations (as seen in herbicide resistant traits) than to increase yield potential of the new cultivars.

Another parameter to be analyzed in the seed market concentration is the product price (in the case of maize seeds with transgenic technology). Dominant industries are interested in controlling the prices of their products. Although the amount of time since the introduction of this technology in Brazil is still short, there is evidence of a trend that the difference in price among genetic modified maize seeds and conventional seed is increasing. However, the most striking effect is found in the reduced prices for conventional seeds (which could be explained by the smaller market acceptance of conventional seeds, or by the concentration of this type of seeds towards products with lower market value, such as double cross hybrids or open pollinated varieties). In order to illustrate these arguments, it is observed in Figure 1 that, so far, there is a trend of increase in sales of transgenic seeds in higher price ranges. On the other hand, in the case of conventional seeds, there is a clear concentration movement of seed sales in smaller price ranges. To support this argument, it should be mentioned that $53.1 \%$ of conventional maize seeds sold in the summer of 2009/10 were priced to $\mathrm{R} \$ 150.00$ (US\$ 75.00), while in the summer of 2011/12 this percentage increased to $78.9 \%$ (Figure 1).

In relation to the types of events that have been used in maize in Brazil (until 2012 cropping season), there is a predominance of $B t$ transgenic single event cultivars, with fewer cultivars with stacked genes (either with different $B t s$ or $B t s+R R$ ). The trend seems to be that the stacked events will increase their participation in the next cropping seasons, but at this moment it is not possible to anticipate if it will reach the American levels. In Brazil, the production systems are more complex than those used in the U.S., with two or more cropping seasons in a single year. In this case, $R R$ events, for example, may present problems for weed management in maize as a second crop, when it would be planted $R R$ maize after $R R$ soybean. This could greatly reduce the time to develop resistance to this herbicide by increasing selection pressure for weed resistance. Another problem that has already been observed in many farms, mainly in Paraná State in Brazil, is that the remnants of a maize crop (ears lost during the crop harvest which stays in the field) can become a problem for the next soybean crop in the $R R$ weed control system. One point that was not raised before is that, even if a farmer wants to cultivate only $B t$ maize (or not to use $B t$ plus $R R$ maize previous to its soybean $R R$ crop), the maize field could be pollinated by a neighbor's $R R$ field, and the remnants ears will have the $R R$ trait. In the 2012 cropping season, a number of farmers had to mechanically control maize plants from the previous crop in the soybean $R R$ fields, because these maize plants competed with soybean plants and also caused problems in the harvest machines.

Facts like those described above would indicate that in the areas where a second crop is cultivated in the same year in Brazil (generally soybean in the summer and maize in the winter), farmers will be interested in acquiring seeds only with $B t$ trait (without $R R$ ). Although, due to the effort to convert conventional inbred lines into transgenic ones for different events, the company's strategy has been to simultaneously use a number of different events in a single inbred line. This would be a first example of possible conflict of interest between the companies that provide the technology,

Table 3. Availability of maize cultivars in the Brazilian market, from 2005/06 to 2012/2013

\begin{tabular}{lllllllll}
\hline Type of cultivar & $2005 / 06$ & $2006 / 07$ & $2007 / 08$ & $2008 / 09$ & $2009 / 10$ & $2010 / 11$ & $2011 / 12$ & $2012 / 13$ \\
\hline Conventional cultivars & 237 & 279 & 278 & 302 & 325 & 361 & 316 & 263 \\
Trangenic cultivars & 0 & 0 & 0 & 19 & 104 & 136 & 173 \\
Total cultivars & 237 & 279 & 278 & 321 & 429 & 497 & 489 & 479 \\
\hline
\end{tabular}

Source: Embrapa Milho e Sorgo 


\section{GMO Seeds}
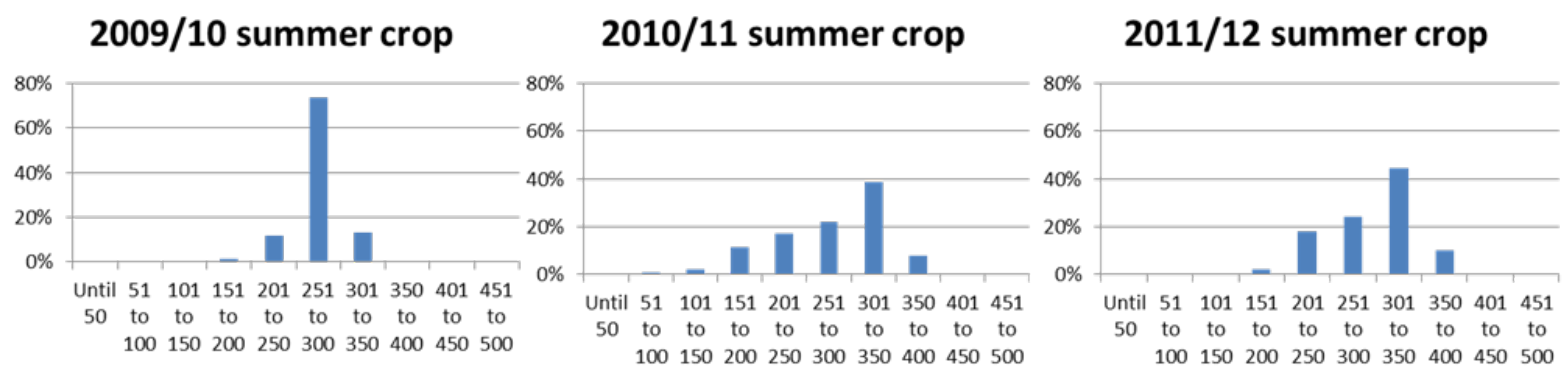

\section{Conventional Seeds}
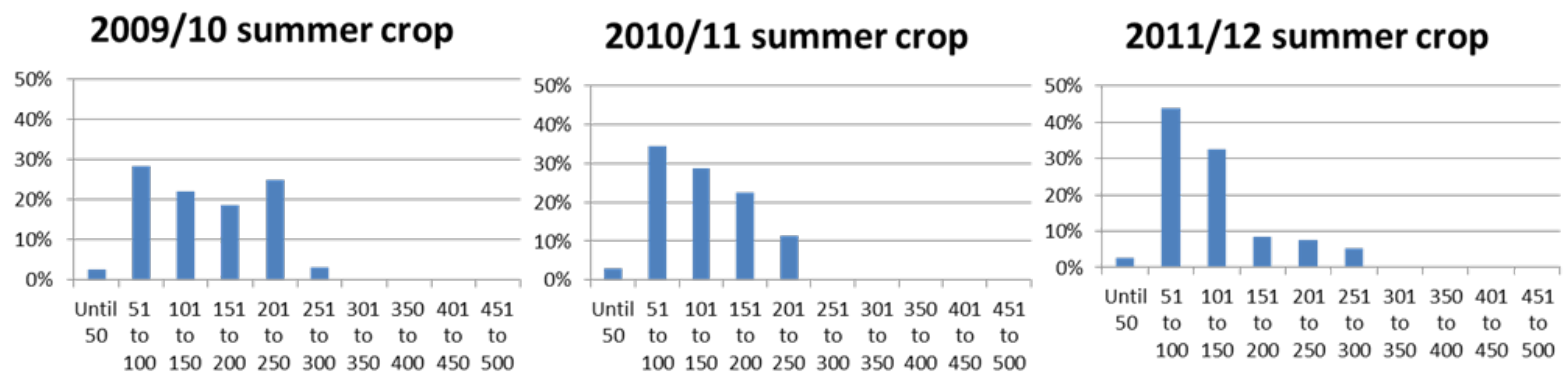

Figure 1. Sales of transgenic and conventional maize seeds, separated by price range (R\$), from 2009/2010 to 2011/2012, in Brazil. Source: Associação Paulista dos Produtores de Sementes e Mudas (APPS).

which are prepared to sell both traits- $B \mathrm{t}$ and $R R$ together in the same cultivar, and the interest of the farmer, who wants to buy only $B t$ trait. It would be relevant to follow what will happen in the future related to this issue.

With the release of transgenic maize in Brazil, in 2012, only four companies had their own transgenic maize products (Monsanto, Dow, Syngenta and DuPont-Pioneer). Monsanto and Dow have adopted the policy of giving to some companies the right of using the traits contained in their proprietary lines. Syngenta and DuPont-Pioneer have prioritized the use of transgenesis only in their own breeding programs. So far in Brazil, the policy of allowing companies which have their own maize breeding programs, to use traits licensed from third parties in its own germplasm, has been almost nonexistent. This indicates that the model which will probably be adopted in Brazil is to pass through contracts/ agreements, both genetics and traits, creating a network of distributors with different trademarks for the genetics and biotechnology of a small number of companies, which hold the technology. The natural consequence of the predominance of the genetics of fewer companies may be a reduction in the genetic base of maize grown in the country, with the risks that it implies, mainly linked to susceptibility of a certain germplasm to specific biotic stresses. The fact of narrowing of the genetic base $\mathrm{x}$ plant disease susceptibility, has oc- curred in different historical periods, and was related to an epidemic caused by the fungus Helminthosporiun Turcicun race $T$. In the 70s, the vast majority of the maize grown in the U.S. and some of the hybrids produced in Brazil were generated using a system of cytoplasmic male sterility based on cytoplasm T. This germplasm showed high sensitivity to Helminthosporiun race $\mathrm{T}$, which, at that time, caused losses of nearly $20 \%$ in the U.S. maize production. In Brazil, the relationship between susceptibility to some disease and maize germplasm of a given company was observed in the $90 \mathrm{~s}$, when the fungus that causes the disease known as grey leaf spot reached the country. During that time, the hybrids of a specific company proved to be much more susceptible to this disease than those ones from other companies, proving the relationship between narrower genetic basis of a single company and susceptibility to a particular disease. These examples showed that the standardization of the germplasm cultivated in the country, through market dominance by a few companies, may increase the risk of maize production, related to losses caused by new diseases and pests.

Another risk related to market concentration concerns the frustration of seed production that may occur in a leading company or a change in demand for seeds in view of situations that indicate increased demand for maize (e.g. drought in Argentina and in the USA in 2012 and expectation of 
Implications on the introduction of transgenics in Brazilian maize breeding programs

higher profitability in the second crop in that year). In the early 2012, in the second cropping season, for the first time it was observed a difficulty for farmers in having access to seed input in the State of Mato Grosso at the desired time and location (Peres 2012). This may become more frequent with the trend of an increasingly concentrated market and without the buffering power of small seed companies.

\section{THE ROLE OF PUBLIC SECTOR AS A SUPPLIER OF MAIZE GERMPLASM AND CULTIVARS IN THE COUNTRY: HISTORY AND NEED FOR PRIVATE-PUBLIC PARTNERSHIPS}

The participation of the public sector as a national supplier of maize germplasm/cultivar in Brazil started in the 60s and 70 s, when there was an important participation of Universities and State Research Institutes, both in the introduction and selection of germplasm for the obtainment of cultivars that were marketed by private companies. Some examples were: the "Universidade Federal de Viçosa", where the company "Agroceres" was originated; the "Escola Superior de Agricultura Luiz de Queiroz ESALQ-USP”, where, under the coordination of Professor Ernesto Paterniani, it was created the largest germplasm collection in the country at the time, and its breeding program produced open pollinated varieties such as Centralmex and Dentado Composto, which were widely used by farmers; the "Estação Experimental de Veranópolis" in the State of Rio Grande do Sul, where it was produced the double cross hybrids SAVE, which had high importance to southern agriculture in that period; and the "Instituto Agronômico de Campinas-IAC", which produced the open pollinated varieties Azteca, Maya and the double cross hybrids from the Hmd series (e.g. Hmd 7974), widely planted in the country, and which were used to initiate Cargill Seeds business in Brazil.

In 1973, the "Empresa Brasileira de Pesquisa Agropecuária-Embrapa" was created by the Brazilian government. Aiming to develop technological solutions for maize and sorghum in the country, the "Centro Nacional de Pesquisa de Milho e Sorgo" was created, and it was initiated a program in the areas of genetics and maize breeding. This program, at first, made a large-scale introduction of improved germplasm in Brazil, derived mainly from CIMMYT-International Maize and Wheat Improvement Center, located in Mexico and also improved materials from other regions such as Suwan in Thailand. The introduced genotypes were crossed with materials adapted to Brazil (usually tall and of late maturity), and as a consequence of this process, about 50 new improved varieties were created and subjected to several cycles of recurrent selection to increase their adaptation to our ecosystems. These genetic materials were widely distributed. From 1980 to the 90 s, about twelve thousand seed samples of these genotypes were distributed to public and private institutions in the country and abroad, and contributed to form the basis of the cultivated maize germplasm in the country.

In the late 70 s and mid-80s, the State and the Universities breeding programs declined their participation as source of cultivar supply to small seed companies in the country. At that time the private sector of maize seed that had already been established in the country became increasingly modern and efficient, and started to invest more in their own breeding programs. However, it began to emerge a new segment of small and medium companies that decided to invest in seed business and to seek partnership with Embrapa. This partnership was efficient in the 80s and 90s due to three main factors: a) the existence in Embrapa of an innovative breeding program that enabled the generation of hybrids and varieties with the following traits: short stature, high productivity, high seed producibility, which increased its economic attractiveness to private sector seed production, adapted to the various regions of the country, including areas of acid soils of the Brazilian Cerrado; b) the implementation of a sector of basic seed production at Embrapa which could, at that time, combined the production of large volumes of parental seeds with an efficient quality control of the seed business generated by these franchisees, and also provide technical and managerial assistance to a large number of small seed companies that were being established in the country; c) the implementation of an innovative model of public-private partnership with clear rules that gave legal and negotiating support to these new partnership arrangements.

This licensing model of public maize genetics to the private sector in the country began to show signs of exhaustion in the mid-90s due to the following factors: a) the competition among licensed companies, which produced the same cultivar; b) companies that had just started their own breeding programs wants to have exclusivity of products and use their own brand in cultivars name, which legally could not be implemented at that time due to public sector rules; c) the initiation of breeding programs in several companies, which started to seek technological partnerships to access inbred lines developed in the public sector, a model which the public sector has failed to implement in that moment; d) the vertical integration of cultivars generation processes started by large companies, involving commercialization, marketing, technical assistance, inputs supply and in some cases, purchase of production, reducing the market space for small and medium companies; e) the release of new maize cultivars with higher yield potential (initially three way crosses, and later, single cross hybrids) by private companies with their own breeding program (which gave support to the actions of item "d" above). For the farmer, 
seed becomes one item in a complex package of supply inputs, services, credit, and commercialization guarantees.

Currently, Embrapa seeks for new models of publicprivate partnerships in the areas of genetic resources and maize cultivars. The focus is to meet the needs of different types of customers ranging from companies that do not have their own breeding program, small and medium companies with their own breeding programs, and even larger companies, which can also transfer to the farmers the benefits achieved by public research. In this sense, new business models are being structured, such as: a) models that give exclusivity and allows the use of its own brand to private companies that want to have access to cultivars produced by the public sector, b) inbred lines licensing models as inputs to obtain jointly public-private hybrids c) "innovation assets", which can be: lines as sources of resistance to biotic or abiotic stresses; markers/Quantitative Trait Loci identified in sources of resistance to these stresses; genes/ knowledge associated with inheritance of these characteristics; methods of screening and phenotyping for specific characteristics; populations (e.g. Recombinant Inbred LinesRILs, association panels, etc) for use in joint programs of genetics/physiology studies of specific characteristics. These advances will only be possible if the public sector will be able to operationalize it in an easy implementation structure of partnerships, within the legal framework to which public sector is subjected in the country.

The national public sector has sought to interact with the owners of traits in pursuit of contractual arrangements that allow the introgression of these traits in inbred lines developed by this sector. This action is in advanced stage in soybean and the expectation is that it also might become feasible in maize and cotton.

It should be emphasized the importance of private sector investment in R\&D in the world and how it is important for the public sector to increasingly seek public-private partnerships. Fuglie et al. (2012a) report that, in 2010, the global private sector investment in R\&D in agricultural inputs totalized US\$ 11 billion, compared to U\$ 5.6 billion in 1994. These authors also analyzed annual sales growth rates in 2006 in different sectors (animal feed, machinery, fertilizers, genetics and animal health, agrochemicals and biotechnology/seed). The highest annual growth rate in sales was seen in the fertilizer sector ( $8.3 \%$ annually), and biotechnology/seed (6.9\% annually) obtained the second highest rate. The total amount of the plant chemical sector sales worldwide in 2010 was US\$ 32 billion, with a growth rate of $1.8 \%$ per year. These numbers indicate that, keeping the annual growth rates observed in that study, by 2020, the market for biotechnology/seed in the world is expected to exceed the market value of agrochemicals.
It should be considered that with the growing concern related to environmental and health issues (climate change, environmental legislation after the Brazilian Forest Code approval, natural resources, etc) the national public sector in the breeding area will also have an important role in the search for solutions for medium/long-term problems such as higher production efficiency (efficient use of nutrients and water); minor impacts on the environment (use of national biodiversity for generating new biological products and its relationship with the genetics of the culture); reduced risks to the consumer (genetics and production technologies that reduce contamination, e.g., by mycotoxins); healthier foods (biofortification with vitamins and minerals). These advances will have significance only if there are efficient mechanisms for transferring them to the private sector (public-private partnerships) in order to make these solutions available to farmers and consumers.

\section{CHALLENGES AND OPPORTUNITIES FOR MAIZE BREEDING PROGRAMS IN THE COUNTRY IN THE POST-TRANSGENICS ERA}

Brazil has been recognized as a major producer of maize, and in recent years it has become an important supplier to the international market. This has happened mostly due to technological adoption than through area expansion (Pereira et al. 2012). Brazilian farmers have proved to be avid for technological innovation to ease their operations and reduce their production risks. In this sense, the "first generation of transgenic" technology has had great acceptance by farmers and there are no signs that it will decrease.

Although the current scenario (2012) is a bit pessimistic about the future of breeding programs and of the medium and small maize seed companies in the country, outside the area of influence of the "biotechnological assets" (or "traits") holders, the survival or not of this national seed sector (which is strategic for national agriculture) will be linked to a sequence of unpredictable events at the time and to the potential scenarios related to them. The analysis of some of these scenarios is made below.

\section{Policy of traits assignment to third parties}

At least three different models of technology transfer in the biotechnological market of traits have been used (Stiegert et al. 2010). The first, known as "licensing model", occurs when the holder is interested in getting a return on investment by receiving a technological fee for the use of the trait, regardless the genetics where it may be. The consequence is that, as more companies use the technology, the greater is the economic return to the company who developed it, with smaller investments for setting 
up a structure for seeds production and marketing. The licensing model "democratizes" the access to the technology, and is the one with less impact on the concentration of the seed sector. The licensing model has been adopted by the holder of $R R 1$ technology in soybeans in Brazil, which has been transferred to several companies in the country. This model maintains a competitive pressure on the market, keeping prices at lower levels. It also permits the survival of a number of breeding programs. As the number of available traits for licensing increases (ex. RR1, $R R 2$ and Bt soybean), the issues related to stewardship of independent events also increase and as a consequence, only more organized companies would be able to follow the innovation pace of the market (the "license model" would become more restrictive regarding to the number of companies that would be eligible to use it).

A second alternative is the model of "authorization to commercialize". In this model, the trait holder selects a number of companies to be the distributors. These companies receive traits and genetics from the holder and get a percentage of sales, like a commercialization fee. Thus, there are two possibilities: first, companies directly receive hybrid seeds and do the processing and packaging with their own brand (it is necessary that the hybrid will be registered on the RNC with the brand of the company that will make the distribution). In other cases, the distributors have access to parental inbred lines, so they can cross them in order to produce hybrid in their own fields, pack and distribute the seeds with their brand. This distribution model causes a "false sense of diversity in the market", where there are different brands, but the genetics belong to a small number of owners, who strictly control the price and quality.

A third form of technology transfer in the biotechnology market is the "vertical integration model". Large companies which hold traits make agreements among them that lead to the stacking of events from different owners (the so called "cross license") in order to obtain new combinations of events, which are currently restricted to the group of the six major maize biotechnology companies. This would be a way of extending the shelf/commercial life of individual traits, recycling them into new combinations. This model also increases the economic return of a trait through its widespread use in different combinations and in a germplasm set that occupy large areas, but under the control of few companies (Wilson and Huso 2008). These agreements do not involve changing intellectual property of the individual components, but according to ETC (2008), it could be defined as a high concentration of technology.

Only in very few cases the owners of traits have given the right of use of these traits in genetics of third parties companies in Brazil. In this scenario, a new term arises, the so called stewardship, which means all the requirements made by the trait owners related to the quality of seed produced by a second company that will use this trait (including aspects of purity, vigor, biological expression of introgressed trait, control of production process with detailed records of all stages, tests for confirmation of purity of the event, etc.), combined with marketing aspects of the company that will receive the trait (including customer information, sales location and volumes, production characteristics, etc). The requirements related to these criteria has been held in such high standards that few companies in the country seem to have conditions to achieve them; thus, they are not considered qualified enough to use a certain trait. Another point is the contractual requirements made by holders when assigning the right of use of traits, which generally have a quite complex structure and include a large number of items, two of which deserve special attention (Cañellas 2012). The first is the right of holders to withdraw from the market certain trait any time they deems appropriate. In this case, all companies that have obtained the right to use the trait must also withdraw from the market all the products containing it. This situation reduces the commercial life time of a cultivar since the introgression of a trait and finalization of VCU tests take from four to five years (depending on the use or not of marker assisted selection), and the expected life of a trait on the market has been estimated around seven years. In many cases, the period of commercialization of a given hybrid with a licensed trait does not pay the costs of equivalency testing (conventional version $\mathrm{x}$ transgenic) and marketing of a hybrid. The second aspect relates to the next topic to be discussed in this paper, which is the expiration of certain patents related to certain trait or even the entry of it in the public domain. The right of use contract agreements, in general, contains clauses that prevent a company from using certain trait after it enters into the public domain. In this case, the company has to choose between signing a contract to have access to the technology in the present, and giving up a future right, which is to be able to have free access to the event after it falls into the public domain.

It is not certain the role that the public sector in the country is likely to have as an intermediary between the owners of traits and national companies, through the access to them in public genetics. The parties involved expect that a progress in these negotiations might be important for the country.

In 2009 the Department of Justice and the USDA held a series of workshops to examine the impacts of market concentration and the market power in different productive chains, including seeds and biotechnology. Some aspects of this work are discussed by Carstensen (2010). The author concludes that the concentration in this market has led to less technological competition and higher input prices. 


\section{Entry of traits in the public domain after expiration of patents}

An expectation of the national seed industry is the possibility of having access to biotechnology events when they come into the public domain after expiration of their patents. The pharmaceuticals are an example, having numerous products known as "generics" being produced in Brazil. However, there are several differences between the regulatory standards of the pharmaceutical sector and biotechnology events, which make this comparison difficult. The first big question is: when should the patent of a certain event expire? This question, although it seems simple, it is complex in nature for several reasons: a) there is no single patent, but a set of patents related to a given event; b) these patents are kept in different countries and this is done at different times, i.e., they will expire on different dates in different countries. A second question concerns the forms of deregulation of events in different countries, and if the product is targeted for domestic consumption (e.g., beans, cassava, etc) or if it is a commodity to be exported to several countries (e.g. soybean, maize, cotton, etc.). Biotechnology products with consumption only in Brazil follow the Brazilian rules, dictated by the CTNBIO and aspects of supervision of the process are done by the Ministry of Agriculture (Mapa). CTNBIO defines issues related to biosafety of an event and is responsible for its authorization for test and use in the country. On the other hand, Mapa supervises the trials approved by CTNBIO, checks issues related to coexistence norms between GMOs and conventional materials and, as part of its activities, it is included the "Serviço Nacional de Proteção de Cultivares - SNPC" (National Plant Variety Protection), which standardizes the registration of varieties (transgenic or conventional). A first difference between transgenic and pharmaceuticals products, is that in many regions of the world (USA and Europe for example), genetic modified materials are connected to at least three regulatory agencies (agriculture, environment and health), whereas pharmaceuticals are generally linked with the health agency. This makes the regulation of processes related to genetic modified organisms in the various countries much more complex than the one related to pharmaceuticals. In relation to products of domestic consumption, it must be verified that in the case of CTNBIO in Brazil, the approval for use of an event in the country is timeless, i.e., once it was approved, this authorization remains valid indefinitely, unless there is a detrimental effect identified on the event. In the case of the U.S. or E.U. countries, these regulatory agencies release the events for a specified period, after which the holder must provide documentation proving that it remains safe. In the case of the U.S., three agencies are involved in this process: the USDA - United State Department of Agriculture (which analyses issues related to agriculture), EPA - Environmental Protection Agency (which analyses environmental issues) and
FDA - Food and Drug Administration (which analyzes health issues). If an event falls into the public domain, it is unclear whether the holder will continue to provide this documentation, and if this does not happen in the case of a commodity like maize, the trading companies probably will put restrictions on the purchase of products with these events (as they will have the same restrictions on exports to other markets). This will certainly have a negative effect on the price of grains from a cultivar containing this event, reducing its acceptance by farmers, and hence its use in breeding programs.

This fact (the possible non acceptance of an event in public domain by legal restrictions on market access) leads to a debate that has recently occurred in the U.S., and concerns two possibilities for a breeding program: a) to keep the conventional breeding program and introgress events in the final stages of the development of inbred lines; $b$ ) to introgress the trait in the program basis. The latter, for example, occurred in soybean breeding program in several North American universities which, for a decade, crossed $R R 1$ materials to obtain new lines with this event. With the possible expiration of the patent right for this event, and if the holder does not provide the documentation required by importing countries, all the breeding program of the last 10 years of those universities would have to be discarded. An alternative would be the "cleaning or removal of the trait" from the germplasm, which would require time and resources. From this discussion, nowadays, all companies have chosen to keep their breeding programs using conventional germplasm and to do the trait introgression at some point during the development of the materials.

Another fact to be considered is that, with the crosslicense, individual events are being used in stacked combinations with other events. Thus, it is expected that if an event is still safe (even after the expiration of its patent) in combination with other events, it should also be considered safe when supplied separately in a hybrid. This subject has been discussed in forums such as the Biotechnology Industry Organization (BIO) and the American Seed Trade Association (ASTA). Recently (USA 2012), these forums announced an agreement called "The Accord in Generic Event Marketability and Access Agreement (GEMAA), signed at this moment by five companies (BASF, Bayer, Dow, DuPont-Pioneer and Monsanto). This agreement was developed to address the transition of commercial biotechnology events as they go off patent. According to this document, the agriculture value chain would benefits from the GEMAA by setting out rights and obligations for signatories involved in commercializing biotechnology seed products containing off-patent biotechnology events to ensure that international regulatory and stewardship responsibilities would be maintained. 
Implications on the introduction of transgenics in Brazilian maize breeding programs

Although there is some expectation about the possibility of using events after they fall into the public domain by breeding programs that do not had access to traits, so far there is no case in the world where this has actually happened. Moreover, the first events to fall into the public domain should be those with the lowest level of technological advancement, since they have been in the market for a long time, compared to events that have been recently released by the holders. A final remark in this issue is related to the fact that the use of a trait for breeding purpose is forbidden by all holders. This point indicates that the process of introgression of public domain trait should only be initiated by a third part company, after it has fallen into public domain. This would delayed even more the possibility of commercially use this trait.

\section{Maize traits generation by companies in the country}

Brazil has been one of the countries that present a large investment in agricultural technology, with numerous universities and research centers with expertise in biotechnology. However, almost all basic researches in the development of traits have been made abroad and mostly funded by the private sector. Some exceptions are the work that have been conducted by Embrapa and partners, which have already led to the approval by CTNBIO of two products for marketing in the country. The first one is a common bean cultivar resistant to golden mosaic virus (Aragão and Faria 2009). The second one, is the Cultivance soybean (Embrapa-BASF partnership), which is resistant to imidazolinone herbicides (Embrapa 2010). Two points should be considered when analyzing the development of transgenics in the country. The first is the technological challenge behind it and the need for complete knowledge of information related to intellectual property throughout the process. The second is related to the deregulation of the event in the target markets. In the case of a domestic consumption product, such as common beans, deregulation activities are conducted exclusively within the country, which facilitates the process. In the case of export commodities, such as soybeans and maize, which deregulation must be done according to the market it may be export to, the challenge of producing and deregulating an event goes far beyond the technological realm of trait generation process. The component of deregulation in global markets for which the product will be exported is still a huge challenge for the private sector, and even more for the public sector. This indicates that in the case of exportable products, the most concrete possibility, in the medium term, of a national institution in developing a transgenic, is associating with a company that has global operations in the area of deregulation. In this sense, the large international seed companies, for being derived mostly from the fields of pharmaceuticals and agrochemicals, already have all the know-how to fulfill the legal requirements for approval of new products into the various regulatory bodies of different countries.

\section{Opportunities for the development of non- transgenic cultivars}

Another possibility for national breeding programs that do not have access to traits would be to focus on the market of non-transgenic cultivars. It is now estimated that in the case of maize, this market makes up for about $20 \%$ of the marketed seed in the country. As for soybeans, there is an international demand for non-transgenic grains (where the importer is willing to pay a premium for this material), in the case of maize, this has not occurred yet. For this reason, in the case of maize, it has been difficult to create a system for prioritizing acquisition of non-transgenic grains. Another opportunity for programs of non-transgenic maize cultivars would be to act preferentially in the medium-low technology market segment. Due to the operational difficulties in introgression, no major company has been working with double crosses transgenic hybrids. In this case, double cross hybrids or conventional open pollinated varieties, suitable for markets with low/medium technology, could be the focus of some programs.

The greatest challenge for a company focused exclusively on developing non-transgenic cultivars is the dispersion of this market. It increases the costs of marketing which is even more serious in relation to products with lower unit value, which is the case of non-transgenic cultivars (see Figure 1). This condition limits the performance of the company to restricted regions, but with a planted area density with conventional seeds, enough to generate a regional demand that justifies the existence of the company. In the United States there are companies that survive in these conditions, complementing their activities with the production and packaging of seeds for other companies that present a wider playing field, which do not want to engage in this segment (this activity, which is a form of outsourcing the physical part of seed production, is also present in Argentina). Another situation that has occurred in the market and that may be related to farmer preference for non-transgenic cultivars is related to the emergence of non-target pests for transgenic events available in the market today, what would lead the farmer to have to re-do one to three, or even more insecticide applications.

As already mentioned, the main maize pest in the country has been the fall armyworm (Spodoptera frugiperda), and maize with $B t$ recent events has focused on controlling it. However, with the large planting areas with events that control this pest, insecticide application was reduced (which 
is environmentally desirable), but the apparent sense of security in relation to insects control caused the farmer to stop making monitoring of pests in agriculture. This opened the way for pests from other cultures, or those previously considered not important in maize, to begin causing considerable damage. The damages caused by sucking insects, such as green belly stink bug (Dichelops spp.), which once was exclusive of soybean, or the damage caused by aphids (Rhopalosiphum maidis) are some examples.

This change in the pattern of pests in transgenic crops can lead to a new situation. The farmer would have to return to using two to three insecticide applications to control secondary pests, which, in regions with lower attack of armyworms, no longer would justify using $B t$ seeds (since it would be necessary to apply insecticide to control non-target pests). In this case, regions and production systems that count with the infrastructure and personnel to make these applications (as occurs in various producers in the State of Mato Grosso, for example), could prove to be more economical to use conventional seed (with high yielding genetics) due to lower cost of this input. In this region, small differences in cost per hectare imply a large amount of revenue due to the scale on which they operate the properties. This would be a new opportunity for conventional breeding programs that would attend to this segment.

Another opportunity for breeding programs that have difficulty in accessing the market in the current scenario would be concentrating on the production of genetic materials (inbred lines, synthetics, populations source etc.) that contain some type of added technology (innovation assets) and that are of interest to other companies in the market. It would include elite lines (not germplasm material, but inbred lines with high combining ability that would be of interest to other programs) which present introgressed characteristics, such as: a) elite lines of high producibility of seed or pollen; b) lines that are sources of disease resistance, preferably with a well characterized genetics, both for plant and pathogen; c) sources of "conventional pest resistance genes", which may increase the shelf life of events when combined with them; d) sources of efficient use of water and nutrients that are long-term studies, in which the private sector has no interest in investing using conventional breeding; e) sources of grain quality (e.g. resistance to mycotoxin) or lines that associate high combining ability with the grain type desired by the market (e.g. orange flint type etc).

Another segment to be exploited by conventional maize breeding programs would be specialized market niches such as sweet corn for canning and in natura consumption, popcorn, biofortified corn, corn with special types of starch or for traditional use (white corn for colonial mills in the South of Brazil, corn grits, corn for pudding and "pamonha", etc). There are signs of breeding companies specializing in meeting some of these segments.

\section{The new order in technological innovation in breeding programs}

In any scenario related to access to transgenic technology, the ultimate goal of a breeding program should be to remain competitive in terms of genetics. This includes meeting the needs of the farmer in productivity, cycle (which in Brazil tends to be earlier in different crops, since the farmer evaluates the profitability of the whole system and not of each crop individually), resistance to pests and diseases (in a world that will value more and more the so called "green agriculture"), yield stability, adaptation to target environments, tolerance to abiotic stresses (drought and high temperatures), nutrients use efficiency, etc. A number of innovations have occurred in maize breeding programs worldwide and Brazilian programs that want to remain competitive must accompany these advances even if on a smaller scale (the idea is not to mimic the large programs, but using innovative techniques in a scale compatible with the size of the company where the program is held). Some of these innovations are: a) use of double-haploid as tools to obtain inbred lines; b) use of marker assisted selection for various reasons such as allocation of lines to heterotic groups, to check the seed purity, or for genetic introgression of different characteristics in elite genotypes; c) use of new methods like Genome Wide Selection involving markers, phenotyping and new biometric models to maximize selection gains; d) use of bioinformatics tools to handle large datasets with phenotypic and genotypic information. The increased use of markers/genotyping in breeding programs can be done either with in-house structures or by contracting another company's service, especially from other countries. This second option seems to be the faster and less expensive to one who wants to access this technology.

An indirect consequence of reducing the number of conventional (non GMO) cultivars in the Brazilian market is that historically they have been an important source of germplasm for some breeding programs in the country (which is permitted by Brazilian law, but not under U.S. law, for example). This should no longer happen with the increase in the participation of the transgenic cultivars in the market. The impact that this restriction will have in the rate of genetic gains in the maize breeding programs in the country is still unknown.

\section{CONCLUSIONS}

Although it has recently been introduced in Brazil, the transgenic cultivars have caused profound changes in the 
seed market sector. Aspects related to the restriction of access to these technologies have been discussed in different forums. It is still unclear how the assignments of use of traits will occur in the future. The outlook is not optimistic, and even if this happens, the conditions related to quality control (stewardship) will be more restrictive than those currently in use by smaller companies.

It is still unclear how to develop the utilization of events in which the intellectual protection has expired. This subject has been discussed in other countries (like the USA) but there is still a number of issues that need to be worked out before this could happen. Anyway, these public domain traits will always be an old technology, which in the maize seed market is usually a reason for lower product prices. Considering that the seed pricing of a particular cultivar involves aspects such as yield potential (incorporating pest resistance, cycle, response to fertilizer doses etc.), marketing actions (such as market presence, ease of acquisition, etc.) and post-sales (technical assistance, credit, acquisition of production, etc.) the technical and economic feasibility of using events in the public domain will take some time to be solved.

It seems certain that the existence of a maize breeding program that does not consider any option of introducing transgenic events has little chance of success. Actions to create a market for non-transgenic grains has had little effect on prices gotten by farmers for this type of product, and it requires a well developed logistic system in the area of segregation and greater control of the process as a whole.

An option for maize breeding programs is the development of parental inbred lines that incorporate certain desirable characteristics to be used for hybrid production by other companies, instead of developing hybrids that need to be introduced in the market. Such innovations could have market value and ensure the survival of these breeding programs.
It must be understood that transgenic technology meant a structural break in the technological process but, at this point, with little impact on the productive potential of plants (the gains are mainly due to issues related to plant protection or convenience of use and do not directly increment the productive potential of these cultivars). Thus, the development of a superior genetics oriented towards the increase of factors affecting crop productivity will always be a constant quest. The problem is how these actions will be incorporated in an environment generated by this new technological paradigm. It will take place mainly in the legal environment (need for clarification of the rules relating to the release of the events covered by some sort of intellectual protection) or in the negotiation between companies. This development, as it occurs with the scientific advancement, is gradual and responds to market conditions of the technologies involved. However, a technical development of breeding programs is vital to its survival and adaptation to the new conditions of the seed market. Programs that fail to innovate will be left behind in terms of genetics. And there is no point having access to traits if there is no superior genetics.

Transgenics for insect control or for herbicide tolerance are important tools that should be used as part of an "Integrated Management System" (IMS) and not as a single strategy. This would be one area where private and public sector could set up partnerships to promote the highest level of technology benefits for farmers use and environmental preservation.

Finally, it should be recognized that commercial agriculture in Brazil in recent decades has opted by technological adoption, and trangenesis is an important component in this segment. Finding a balance between the remuneration of private investment in innovation and an appropriate structure of the seed industry market is a complex task to be defined by Brazilian society.

\title{
Implicações da introdução de milho transgênico nos programas brasileiros de melhoramento
}

\begin{abstract}
Resumo - A tecnologia de transgênicos em milho no Brasil foi liberada em 2008/2009 e em 2012 ocupou $73 \%$ da área de milho. Esta alta taxa de adoção confirma estudos que indicam que a opção por uso de tecnologia tem sido o principal fator do desenvolvimento da agricultura nacional. O mercado de sementes de milho no mundo em geral é concentrado, mas a transgenia ampliou esta concentração. De um lado, há a ideia que as empresas podem se beneficiar dos ganhos de escala e complementaridades para maximizar sua eficiência de Pesquisa e Desenvolvimento. De outro, esta concentração pode permitir o exercício do chamado "poder de mercado" pelas empresas dominantes. O objetivo deste artigo foi analisar os impactos da adoção desta tecnologia no arranjo dos programas de melhoramento e no setor brasileiro de produção de sementes. Uma análise crítica da situação dos programas de melhoramento que não detêm esta tecnologia é feita.
\end{abstract}

Palavras-chave: Melhoramento de milho, concentração do mercado de sementes, transgenia. 


\section{REFERENCES}

Antonialli AF (2012) Impacto das cultivares transgênicas nas empresas nacionais de sementes de milho. In MEZ Paterniani, AP Duarte and A Tsunechiro (eds.) XXIX Congresso nacional de milho e sorgo. Editores Aildson Pereira Duarte, Maria Eliza Zagatto Paterniani e Alfredo Tsunechiro., Águas de Lindóia, p. 161-172.

Aragão FJL and Faria JC (2009) First transgenic geminivirus-resistant plant in the field. Nature Biotechnology 27: 1086-1088.

Cañellas AM (2012) El control de producción de semillas transgénicas por medio de contratos. Available at $<$ http://www.indret.com/ pdf/873_es.pdf $>$ Accessed on Oct 30, 2012.

Carstensen PC (2010) Comments for the United States Department of Agriculture and Justice workshops on competition issues in agriculture. University of Wisconsin Legal Studies Research Paper nr 1103: 25 pg.

Elzinga KG (1977) The goals of antitrust: other than competition and efficiency, what else counts? University of Pennsylvania Law Review 125: 1191-1213.

Embrapa (2010) Soja Cultivance recebe aprovação para cultivo comercial no Brasil. Available at $<$ http://www.embrapa.br/imprensa/ noticias/2010/fevereiro/1a-semana/soja-cultivanceae-da-basf-eda-embrapa-recebe-aprovacao-para-cultivo-comercial-no-brasil> Accessed on Oct 30, 2012.

ETC (2008) Who owns nature? Corporate power and the final frontier in the commodification of life. ETC Group, Ottawa, 52p.

Fernandez-Cornejo J (2004) The seed industry in U.S. agriculture: an exploration of data and information on crop seed markets, regulation, industry structure, and research and development. USDA, Washington DC, 81p. (Agriculture Information Bulletin, 786).

Fuglie K, King J, Heisey P and Schimmelpfennig D (2012a) Private industry investing heavily, and globally in research to improve agriculture productivity. Economic Research Service/USDA. Amber Waves 10: 2, 6 p. Available at <http://www.ers.usda.gov/amberwaves/2012-june/private-industry.aspx $>$ Accessed on Oct 30, 2012.

Fuglie K, King J, Heisey P and Schimmelpfennig D (2012b) Rising concentration in agricultural input industries influences new farm technologies. Economic Research Service/USDA. Amber Waves 10: 4, 6 p. Available at $<$ https://correio.embrapa.br/service/home/ /risingconcen trationinputindustry.pdf?auth $=$ co\&loc $=$ pt_BR\&id $=$ db4ca02e-b3a8-44a28f7d-7899a844303d:305\&part=2> Accessed on Dec 13, 2012.
Guerrante RDS (2011) Estratégia de inovação e tecnologia em sementes. Universidade Federal do Rio de Janeiro, Escola de Química, Rio de Janeiro, 269p. (PhD Thesis).

Howard PH (2009) Visualizing consolidation in the global seed industry: 1996-2008. Sustainability 1: 1266-1287.

Pereira, PAA, Martha Jr. GB, Santana CAM and Alves EE (2012) The development of Brazilian agriculture: future technological challenges and opportunities.Agriculture \& Food Security 1: 4.

Peres M (2012) Milho: frustração no campo em Mato Grosso. Diário de Cuiabá. Available at < http://www.agrolink.com.br/noticias/ ClippingDetalhe.aspx?CodNoticia $=166058>$ Accessed on Feb 27, 2012.

Schimmelpfenning DE, Pray CE and Brennan MF (2004) The impact of seed industry concentration on innovation: a study of US biotech market leaders. Agricultural Economics 30: 157-167.

Shin G and Chavas JP (2010) On pricing and vertical organization of differentiated products. Food System Research Group, Working Paper 2010-06. 38p.

Shin G, Chavas JP and Stiegert KW (2010a) An analysis of the pricing of the traits in the US maize seed market. American Journal of the Agricultural Economics 92: 1325-1338.

Shin G, Stiegert KW and Chavas JP (2010b) An analysis of bundle pricing in horizontal and vertical markets: the case of the U.S. cotton seed market. Food System Research Group, Working Paper 2010-06. 38p.

Silva FF, Braga MJ and Garcia JC (2012) Inovação e concentração nos mercados de sementes de milho, soja e algodão. In Anais do I congresso brasileiro de economia e sociologia rural. UFES, Vitória, CD-ROM.

Stiegert KW, Shi G and Chavas JP (2010) Innovation, integration, and the biotechnology revolution in U.S. seed markets. Choices 25: $1-7$.

Wilson W and Huso S (2008) Trait stacking, licensing and seed firm acquisitions in genetically modified grains: a strategic analysis. Journal of Agricultural and Resource Economics 33: 382-401.

USA (2012) The accord: generic event marketability and access agreement is now effective. Available at $<$ http://www.seedquest. com $/$ news.php?type $=$ news\&id_article $=31451 \&$ id_region $=\&$ id category $=191 \&$ id $c r o p=>$ Accessed on Dec 17, 2012. 